\title{
Florida's Citrus Canker Eradication Program (CCEP): Annual Economic Impact on Florida's Specialty Citrus Fruit Market ${ }^{1}$
}

Thomas H. Spreen, Marisa L. Zansler, and Ronald P. Muraro²

Rapid expansion and integration of international trade, increased tourism, and changes in methods of production in recent decades have increased the likelihood of the introduction of invasive species to U.S. (United States) agriculture. Invasive species can have adverse environmental and/or economic impacts when introduced into a region. Economic impacts include marketing, production, and trade implications.

One such invasive species imposing adverse economic impacts to the Florida citrus industry is a bacterial disease known as citrus canker (caused by Xanthomonas axanopodis pv. citri). Citrus canker causes lesions on the leaves, stems, and fruit of citrus trees. The disease adversely affects the proportion of fruit intended for the fresh market, serves to weaken citrus trees, and leads to a reduction in yields and higher costs of production.

The Citrus Canker Eradication Program (CCEP) was implemented in the mid-1990s in an attempt to establish guidelines for averting the spread of the disease. Currently there is no biological or chemical cure for citrus canker. All infected trees and citrus trees within a radius of 1900 feet of an infected tree must be eradicated. On-site decontamination of grove workers, field equipment, and packinghouses is also mandatory to prevent the spread of the disease.

The current effort to eradicate citrus canker from the industry, the Citrus Canker Eradication Program (CCEP), has been mired in controversy associated with public opinion and legal action. A benefit-cost analysis was conducted to determine if the CCEP is, indeed, a useful policy tool in combating the economic ramifications associated with citrus canker.

In the analysis presented in this paper, the benefits of the Citrus Canker Eradication Program (CCEP) on Florida's specialty citrus fruit industry are estimated through an analysis of the Florida citrus industry under the scenario that citrus canker has become established, holding all other factors constant. The net change in revenue in the fresh and processed markets and the additional costs of

1. This is EDIS document FE535, a publication of the Department of Food and Resource Economics, Florida Cooperative Extension Service, Institute of Food and Agricultural Sciences, University of Florida, Gainesville, FL. Published August 2005. Please visit the EDIS website at http://edis.ifas.ufl.edu.

Note: This article is one of a series of EDIS articles on the economic impacts of citrus canker on Florida's citrus industry. The series is available at http://edis.ifas.ufl.edu/TOPIC_CCEP.

2. Thomas H. Spreen, Professor and Chairman, Food and Resource Economics Department; Marisa L. Zansler, Economist, Policy Analysis and Development, APHIS-USDA; and Ronald P. Muraro, Professor and Extension Economist, Department of Food and Resource Economics, Citrus Research and Education Center, Lake Alfred, FL, Florida Cooperative Extension Service, Institute of Food and Agricultural Sciences, University of Florida, Gainesville, FL.

The Institute of Food and Agricultural Sciences (IFAS) is an Equal Opportunity Institution authorized to provide research, educational information and other services only to individuals and institutions that function with non-discrimination with respect to race, creed, color, religion, age, disability, sex, sexual orientation, marital status, national origin, political opinions or affiliations. U.S. Department of Agriculture, Cooperative Extension Service, University of Florida, IFAS, Florida A. \& M. University Cooperative Extension Program, and Boards of County Commissioners Cooperating. Larry Arrington, Dean 
production were the measurements of the estimated benefits.

\section{Specialty Citrus Fruit Analysis}

Specialty fruit varieties include honey tangerines, early tangerines, tangelos, temple oranges, and navel oranges. It is assumed that total production of honey tangerines, early tangerines, and navel oranges is initially sent to the packinghouse. However, a portion of the total production of tangelos and temple oranges is shipped directly to the processing plant, making it difficult to measure the economic impact of reduced packout rates on these specialty varieties. Because of the way these varieties are segregated between the packinghouse and the processing plant, more fruit may be sent to the packinghouse to maintain supply on the fresh market in an industry with endemic citrus canker. Therefore, this study assumes that every attempt will be made to maintain supply on the fresh market due to the reduced availability of oranges for the fresh market. As such, it is assumed that citrus canker will not have an economic impact on fresh utilization of temples and tangelos.

\section{Annual Returns for the Fresh and Processed Speciality Citrus Fruit Market in Florida}

Results of the projected economic impact of endemic citrus canker on the annual per acre returns for Florida fresh and processed honey tangerines, early tangerines, and navel oranges are reported in Table 1. If citrus canker were to become endemic to Florida, total production of honey tangerines, early tangerines, and navel oranges could decrease by ten percent. As a result, fresh utilization of honey tangerines would decrease by 837 thousand boxes, from 1.8 million to 954 thousand boxes; fresh utilization of early tangerines would decrease by 1.1 million boxes, from 2.6 million to 1.5 million boxes; and fresh utilization of navel oranges would decrease by 1.7 million boxes, from 3.6 million to 1.9 million boxes. However, a significant increase in projected on-tree price per box could greatly offset the reduction in fresh utilization. For example, fresh on-tree revenue would increase from approximately \$18.6 million to \$32 million for honey tangerines, from approximately $\$ 25$ million to $\$ 46.3$ million for early tangerines, and from approximately $\$ 23.2$ million to $\$ 32.6$ million for navel oranges. Increased allocation of specialty fruit to the processing plant would increase processed revenue in an endemic canker situation since price is not expected to change. The redistribution of fruit for processed utilization would increase by 67 percent for honey tangerines, from 859 thousand boxes to 1.4 million boxes; by 37 percent for early tangerines, from 1.7 million boxes to 2.3 million boxes; and by 61 percent for navel oranges, from 1.8 million boxes to 2.9 million boxes. As a result, processed on-tree revenue would increase from $\$ 1.1$ million to $\$ 1.9$ million for honey tangerines, from $\$ 1.7$ million to $\$ 2.4$ million for early tangerines, and from $\$ 597,000$ to $\$ 962,000$ for honey tangerines.

In addition, total on-tree revenue for specialty citrus fruit would increase from $\$ 19.7$ million to $\$ 33.9$ million for honey tangerines, from $\$ 26.7$ million to $\$ 48.7$ million for early tangerines, and from $\$ 23.7$ million to $\$ 32.6$ million for navel oranges. Overall gain in total on-tree revenue for fresh and processed utilization of honey tangerines, early tangerines, and navel oranges is estimated at $\$ 44.9$ million.

Results of the estimated economic impact of endemic citrus canker on the annual per acre returns for Florida fresh and processed tangelos and temple oranges are reported in Table 2. Note that fresh utilization will not experience an economic impact since supply will be sustained on the fresh market. If citrus canker were to become endemic to Florida, total production of tangelos and temple oranges could decrease ten percent, which would result in decreased on-tree revenues of processed tangelos and temple oranges. If these fruits were diverted from the fresh market, processed utilization of temple oranges would decrease slightly from 1.51 million boxes to 1.32 million boxes and processed utilization of tangelos would decrease slightly from 1.46 million boxes to 1.24 million boxes. As a result, processed on-tree revenue would decrease $\$ 206,000$ for temple oranges, from approximately $\$ 2.5$ million to $\$ 2.3$ million, and $\$ 220,000$ for tangelos, from approximately $\$ 1.5$ million to $\$ 1.2$ million. 
Overall loss in on-tree revenue for fresh and processed utilization of temples and tangelos is estimated at $\$ 426,000$. Overall gain in total on-tree revenue for fresh and processed utilization of honey tangerines, early tangerines, and navel oranges is estimated at $\$ 44.9$ million. Overall revenue gain in revenue of specialty fruit in an endemic citrus canker industry is estimated at $\$ 44.5$ million.

\section{Economic Impacts of Endemic Citrus Canker in Florida on Specialty Citrus Fruit F.O.B. Revenue}

Estimated economic impact of endemic citrus canker on specialty citrus fruit F.O.B. revenue is reported in Table 3 using the Florida Citrus Administrative Committee's (CAC, 2000) report on annual total marketings and F.O.B. (freight on board) prices, and the 1999-2000 season quantity and price information. While it is assumed that F.O.B.

revenues for temple oranges and tangelos will remain unaffected, this is not the case for F.O.B. revenunes for early tangerines, honey tangerines, and navel oranges. The baseline model is adjusted to reflect a citrus canker endemic industry by reducing the packout rates by one-third and adjusting quantities to reflect a ten percent yield reduction. As a result, packout rates decline from 60.5 percent to 40.3 percent for early tangerines, from 67.5 percent to 45 percent for honey tangerines, and from 66.5 percent to 44.3 percent for navel oranges. A marketing margin for each variety is derived by dividing the difference between F.O.B. revenues and on-tree revenues. The marketing margin is then used to derive the on-tree price per carton. Demand elasticity for retail is estimated at -0.7 for on-tree fresh and processed specialty fruit, except honey tangeries and early tangerines whose demand elasticity at the grower level is estimated at -0.45 (Brown, 1993). Marketing margin is used to derive the on-tree price per carton. Results of the model estimate an increase in F.O.B. revenues for early tangerines and honey tangerines of $\$ 8.4$ million and 6.1 million, respectively, and a decrease in F.O.B. revenues for navel oranges decrease of approximately $\$ 3.6$ million annually. The total economic impact of endemic citrus canker on F.O.B. revenue for early tangerines, honey tangerines, and navel oranges is an estimated gain of $\$ 10.9$ million.

\section{Economic Impact of Citrus Canker on Packinghouse Costs of Specialty Fruit}

F.O.B. costs of producing early tangerines, honey tangerines, navel oranges, temple oranges, and tangelos for the fresh market are estimated for a citrus canker endemic industry. The impact of citrus canker on the estimated F.O.B. packinghouse cost for early tangerines is reported in Table 4 . The estimated production cost (which include growing, harvesting, hauling, and packing) of early tangerines is shown based on the figures provided by Muraro, Roka, and Rouse (2000). In those production budgets, early tangerine groves, under the assumption of 253 boxes per acre yield and a 60 percent fresh market (packout) at 60 percent yield, are analyzed (FASS, 2000).

Assuming that citrus canker reduces fruit yield by ten percent, per acre yield declines from 253 boxes to 228 boxes per acre, total cartons of early tangerines that can be marketed from one acre with a 60 percent packout are 455 (two cartons per box). Furthermore, assuming the packout rate declines by one-third with citrus canker, per acre fresh market utilization with endemic citrus canker is reduced from 304 cartons to 182 cartons per acre. When adjusted to per carton, growing costs increase by approximately 67 percent, from $\$ 3.14$ to $\$ 5.23$ per carton. Other costs (which include interest on operating costs, management costs, taxes, and interest on capital investment) increase 67 percent from $\$ 1.82$ per carton to $\$ 3.03$ per carton. Harvesting costs (which include pick-and-haul) increase from $\$ 3.29$ per carton to $\$ 4.93$ per carton.

Overall, total delivered-in costs (grove care and harvesting costs) are estimated to increase by approximately 60 percent, from $\$ 8.25$ per carton to $\$ 13.19$ per carton. Packing and selling costs increase from $\$ 3.71$ per carton to $\$ 4.18$ per carton with the addition of certification fees and decontamination costs. Certification fees and decontamination costs were obtained from a study on estimating grower costs associated with endemic citrus canker in Florida (Muraro, Roka, and Spreen, 2001). The delivered-in net value of fresh eliminations (fruit not acceptable for the fresh market) is the average yield of pound solids per box times price per pound solids minus the 
packinghouse elimination charge of $\$ 1.03$ per box. After factoring in the credit associated with net costs of eliminations, total F.O.B. costs at the packinghouse level for early tangerines increase by roughly 36 percent with endemic canker, from $\$ 10.98$ per carton to $\$ 14.93$ per carton.

The impact of citrus canker on the estimated F.O.B. packinghouse cost for honey tangerines is reported in Table 5. The estimated production cost (which includes growing, harvesting, hauling, and packing) of honey tangerines is shown based on the figures provided by Muraro, Roka, and Rouse (2000). In those production budgets, honey tangerine production is 298 boxes per acre yield with a 60 percent fresh market packout yield, or 358 cartons (FASS, 2000). Assuming that citrus canker reduces fruit yield by ten percent to 268 boxes per acre and packout rate declines by one-third with citrus canker, fresh market utilization with endemic citrus canker is reduced from 358 cartons to 215 cartons per acre.

When adjusted to per carton, growing costs increase by approximately 67 percent, from $\$ 3.06$ per carton to $\$ 5.10$ per carton. Other costs (which include interest on operating costs, management costs, taxes, and interest on capital investment) increase 66 percent, from $\$ 1.55$ per carton to $\$ 2.58$ per carton. Harvesting costs (which include pick-and-haul) increase from $\$ 2.79$ per carton to $\$ 4.19$ per carton.

Overall, total delivered-in costs are projected to increase by approximately 60 percent, from $\$ 7.39$ per carton to $\$ 11.86$ per carton. Packing and selling costs increase from $\$ 3.71$ per carton to $\$ 4.11$ per carton with the addition of certification fees and decontamination costs. Certification fees and decontamination costs were obtained from a study on estimating grower costs associated with endemic citrus canker in Florida (Muraro, Roka, and Spreen, 2001).

The net value of fresh eliminations is the average yield of pound solids per box times price per pound solids minus the packinghouse elimination charge of $\$ 1.03$ per box. After factoring in the credit associated with net costs of eliminations, total F.O.B. costs at the packinghouse level for honey tangerines increase by roughly 34 percent with endemic canker, from $\$ 10.13$ per carton to $\$ 13.52$ per carton.
The impact of citrus canker on the estimated F.O.B. packinghouse cost for navel oranges is reported in Table 6 . The estimated production cost (which includes growing, harvesting, hauling, and packing) of navel oranges is shown based on the figures provided by Muraro, Roka, and Rouse (2000). In those production budgets, navel orange production is 240 boxes per acre yield with a 60 percent fresh market packout yield, or 288 cartons (FASS, 2000). Assuming that citrus canker reduces fruit yield by ten percent to 216 boxes per acre, the packout rate declines by one-third with citrus canker, fresh market utilization with endemic citrus canker is reduced from 288 cartons to 173 cartons per acre. Growing costs per acre increase through costs associated with additional copper applications, from $\$ 837.15$ per acre to $\$ 869.51$ per acre. When adjusted to per carton, growing costs increase by approximately 73 percent, from $\$ 2.91$ per carton to $\$ 5.03$ per carton. Other costs (which include interest on operating costs, management costs, taxes, and interest on capital investment) increase 67 percent, from $\$ 1.92$ to $\$ 3.20$ per carton. Harvesting costs (which include pick-and-haul) increase from $\$ 3.47$ per carton to $\$ 5.20$ per carton.

Overall, total delivered-in costs are projected to increase by approximately 62 percent, from $\$ 8.29$ per carton to $\$ 13.43$ per carton. Packing and selling costs increase from $\$ 3.71$ per carton to $\$ 4.37$ per carton with the addition of certification fees and decontamination costs. Certification fees and decontamination costs were obtained from a study on estimating grower costs associated with endemic citrus canker in Florida (Muraro, Roka, and Spreen, 2001).

The net value of fresh eliminations (fruit not acceptble for the fresh market) is the average yield of pound solids per box times price per pound solids minus the packinghouse elimination charge of $\$ 1.03$ per box. After factoring in the credit associated with net costs of eliminations, total F.O.B. costs at the packinghouse level for navels increase by roughly 42 percent with endemic canker, from $\$ 11.34$ per carton to $\$ 16.13$ per carton.

The impact of citrus canker on the estimated F.O.B. packinghouse cost for tangelos is reported in 
Table 7. The estimated production cost (which includes growing, harvesting, hauling, and packing) of tangelos is shown based on the figures provided by Muraro, Roka, and Rouse (2000). In those production budgets, tangelo production is 195 boxes per acre yield with a 60 percent fresh market packout yield, or 234 cartons (FASS, 2000). Assuming that citrus canker reduces fruit yield by ten percent, per acre yield declines from 195 boxes to 176 boxes per acre. Furthermore, assuming the packout rate declines by one-third with citrus canker, fresh market utilization with endemic citrus canker is reduced from 234 cartons to 140 cartons per acre. Growing costs per acre increase through costs associated with additional copper applications, from $\$ 837.15$ per acre to $\$ 869.51$ per acre. When adjusted to per carton, growing costs increase by approximately 73 percent, from $\$ 2.58$ to $\$ 6.19$ per carton. Other costs (which include interest on operating costs, management costs, taxes, and interest on capital investment) increase 67 percent from $\$ 2.36$ per carton to $\$ 3.94$ per carton. Harvesting costs (which include pick-and-haul) increase from $\$ 4.27$ per carton to $\$ 6.40$ per carton.

Overall, total delivered-in costs are estimated to increase by approximately 62 percent, from $\$ 10.20$ per carton to $\$ 16.52$ per carton. Packing and selling costs increase from $\$ 3.71$ per carton to $\$ 4.32$ per carton with the addition of certification fees and decontamination costs. Certification fees and decontamination costs were obtained from a study on estimating grower costs associated with endemic citrus canker in Florida (Muraro, Roka, and Spreen, 2001).

The net value of fresh eliminations is the average yield of pound solids per box times price per pound solids minus the packinghouse elimination charge of $\$ 1.03$ per box. After factoring in the credit associated with net costs of eliminations, total F.O.B. costs at the packinghouse level for tangelos increase by roughly 42 percent with endemic canker from $\$ 12.94$ to $\$ 18.40$ per carton.

The impact of citrus canker on the estimated F.O.B. packinghouse cost for temple oranges is reported in Table 8. The estimated production cost (which includes growing, harvesting, hauling, and packing) of temple oranges is shown based on the figures provided by Muraro, Roka, and Rouse (2000). In those production budgets, temple orange production is 336 boxes per acre yield with a 60 percent fresh market packout yield, or 403 cartons (FASS, 2000). Assuming that citrus canker reduces fruit yield by ten percent, per acre yield declines from 336 boxes to 302 boxes per acre. Furthermore, assuming the packout rate declines by one-third with citrus canker, fresh market utilization with endemic citrus canker is reduced from 403 cartons to 242 cartons per acre. Growing costs per acre increase through costs associated with additional copper applications, from $\$ 837.15$ per acre to $\$ 869.51$ per acre. When adjusted to per carton, growing costs increase by approximately 73 percent, from $\$ 2.08$ per carton to $\$ 3.59$ per carton. Other costs (which include interest on operating costs, management costs, taxes, and interest on capital investment) increase 66 percent, from $\$ 1.37$ to $\$ 2.28$ per carton. Harvesting costs (which include pick-and-haul) increase from $\$ 2.48$ per carton to $\$ 3.71$ per carton.

Overall, total delivered-in costs are estimated to increase by approximately 62 percent, from $\$ 5.92$ per carton to $\$ 9.59$ per carton. Packing and selling costs increase from $\$ 3.71$ per carton to $\$ 4.06$ per carton with the addition of certification fees and decontamination costs. Certification fees and decontamination costs were obtained from the study on estimating grower costs associated with endemic citrus canker in Florida (Muraro, Roka, and Spreen, 2001).

The net value of fresh eliminations is the average yield of pound solids per box times price per pound solids minus the packinghouse elimination charge of $\$ 1.03$ per box. After factoring in the credit associated with net costs of eliminations, total F.O.B. costs at the packinghouse level for temple oranges increase by roughly 30 percent with endemic canker, from $\$ 8.66$ per carton to $\$ 11.21$ per carton.

\section{Total Net Change in Cost of Production}

Estimated changes in packinghouse production costs for Florida early tangerines, honey tangerines, tangelos, navel oranges, and temple oranges in an 
endemic citrus canker industry are reported in Table 9.

Total packinghouse production of early tangerines is estimated to decrease from 5.3 million to approximately 4.8 million cartons in an endemic citrus canker industry. Referring to Table 4, total F.O.B. costs for early tangerines in an endemic citrus canker industry increase from $\$ 10.98$ per carton to $\$ 14.93$ per carton. As a result, F.O.B. costs for early tangerines increase by approximately $\$ 13$ million, from $\$ 58.2$ million to $\$ 71.2$ million for the industry.

Total packinghouse production of honey tangerines is estimated to decrease from 8.7 million to approximately 7.8 million cartons in an endemic citrus canker industry. Total F.O.B. costs for honey tangerines in an endemic citrus canker industry increase from $\$ 10.13$ per carton to $\$ 13.52$ per carton (Table 5). As a result, F.O.B. costs for honey tangerines increase by approximately $\$ 17.7$ million, from $\$ 88.1$ million to $\$ 105.9$ million for the industry.

Total packinghouse production of navel oranges is estimated to decrease from 10.8 million to approximately 9.7 million cartons in an endemic citrus canker industry. Total F.O.B. costs for navel oranges in an endemic citrus canker industry increase from $\$ 11.34$ per carton to $\$ 16.13$ per carton (Table 6). As a result, F.O.B. costs for navel oranges increase by approximately $\$ 34$ million, from $\$ 122.5$ million to $\$ 156.8$ million for the industry.

It is assumed that the portion of tangelos and temples shipped directly to the processing plant will remain unchanged. As such, it is difficult to measure the economic impact of a low packout rate. Prices for processed fruit are estimated to increase due to increased production costs. Total F.O.B. costs for tangelos and temple oranges in an endemic citrus canker industry increase from $\$ 12.94$ per carton to $\$ 18.40$ per carton (Table 7) and $\$ 8.66$ per carton to $\$ 11.21$ per carton (Table 8), respectively. As a result, industry F.O.B. costs for temple oranges and tangelos increase from approximately $\$ 12.7$ million to $\$ 16.4$ million for temple oranges and from approximately $\$ 31.8$ million to $\$ 45.2$ million for tangelos. The total change in F.O.B. costs for specialty varieties increases by $\$ 82$ million.

\section{Summary of Benefits}

Table 10 summarizes the estimated net change in revenue of the fresh and processed specialty market when citrus canker is introduced. Under the conditions associated with endemic citrus canker, the fresh and processed specialty fruit market experiences gains in excess of $\$ 44.5$ million due to a significant increase in prices. The fresh and processed markets for specialty fruits are estimated to experience net revenue gains of $\$ 43.1$ million and $\$ 1.3$ million, respectively.

The estimated net change in F.O.B. revenue for specialty citrus fruit associated with endemic citrus canker is reported in Table 11. Early tangerines and honey tangerines are estimated to experience net gains in F.O.B. revenues of $\$ 8.4$ million and $\$ 6.1$ million, respectively. Navel oranges are estimated to experience a net loss of $\$ 3.6$ million. Overall, F.O.B. revenue for specialty citrus is estimated to increase $\$ 10.9$ million.

Table 12 summarizes the estimated net change in the production costs of specialty fruit sent to the packinghouse in an endemic citrus canker industry. Packinghouse production costs of early tangerines, honey tangerines, navel oranges, temple oranges, and tangelos are projected to increase by $\$ 13$ million, \$17.8 million, \$34.3 million, \$3.7 million, and \$13.4 million, respectively. The total change in F.O.B. costs of production for specialty varieties is estimated to increase by $\$ 82.2$ million.

The overall annual net economic benefits of the CCEP on Florida's specialty citrus fruit under an endemic citrus canker scenario are summarized in Table 13.

Delivered-in costs are estimated to increase by $\$ 82.2$ million. However, the combined annual on-tree and F.O.B. revenues are expected to increase $\$ 55.3$ million. The annual net increase in costs for specialty citrus is estimated to be $\$ 26.8$ million.

The effects of the 2004 hurricane season add a new unknown in the CCEP economic analysis since the citrus canker bacteria disease is spread by rain-driven wind. Results for the economic analysis were developed in June of 2004 before Hurricanes 
Charley, Francis, and Jeanne passed through Florida.

Continuation of the CCEP beyond 2008 would

require a new study to estimate the economic impact of the additional costs of the CCEP along with the losses incurred by Florida's citrus industry.

\section{References}

Brown, M.A., T.H. Spreen, and R.P. Muraro. 1999. Fresh versus Processed Utilization of Florida Grapefruit. Journal of Food Distribution Research 30(3):22-32.

Citrus Administrative Committee (CAC). 2000. Specialty Fruit Annual Report. CAC, Lakeland, FL. Available online at http://citrusadminstrativecommittee.org and at http://www.citrusadministrativecommittee.org/ shippersreport/annualreport/annual_special.pdf .

Florida Agricultural Statistical Service (FASS). 2000. Citrus Summary 1999-2000. FASS, Orlando, FL.

Muraro, R.P., J.W. Hebb, and E.W. Stover. 2000. Budgeting Costs and Returns for Indian River Citrus Production, 1999-2000. Economic Information Report EI-01-07. Department of Food and Resource Economics, University of Florida, Gainesville, FL (December).

Muraro, R.P., F.M. Roka, and R.E. Rouse. 2000. Budgeting Costs and Returns for Southwest Florida Citrus Production, 1999-2000. Economic Information Report EI-00-07. Department of Food and Resource Economics, University of Florida, Gainesville, FL (December).

Muraro, R. P., F. M. Roka, and T. H. Spreen. 2001a. An Overview of Argentinas Citrus Canker Control Program. Electronic Data Information Source (EDIS) FE285. Department of Food and Resource Economics, UF/IFAS, University of Florida, Gainesville, FL (June).

Muraro, R. P., F. M. Roka, and T. H. Spreen. 2001b. Grower Costs of Having Citrus Canker in Florida. Electronic Data Information Source (EDIS) FE286. Department of Food and Resource Economics, UF/IFAS, University of Florida, Gainesville, FL (June). 
Florida's Citrus Canker Eradication Program (CCEP): Annual Economic Impact on Florida's....

Table 1. Estimated economic impact of endemic citrus canker on annual returns of fresh and processed honey tangerines, early tangerines, and navel oranges, 1999-2000 season.

\begin{tabular}{|c|c|c|c|c|c|c|c|}
\hline \multirow[t]{2}{*}{ Variety } & \multicolumn{3}{|c|}{ Fresh Fruit } & \multicolumn{3}{|c|}{ Processed Fruit } & \multirow{2}{*}{$\begin{array}{l}\text { On-Tree } \\
\text { Revenue* }\end{array}$} \\
\hline & $\begin{array}{c}\text { Fresh } \\
\text { Utilization }\end{array}$ & $\begin{array}{c}\text { Fresh } \\
\text { On-Tree } \\
\text { Price }\end{array}$ & $\begin{array}{l}\text { Fresh } \\
\text { On-Tree } \\
\text { Revenue }\end{array}$ & $\begin{array}{c}\text { Processed } \\
\text { Utilization }\end{array}$ & $\begin{array}{c}\text { Processed } \\
\text { On-Tree } \\
\text { Price }\end{array}$ & $\begin{array}{l}\text { Processed } \\
\text { On-Tree } \\
\text { Revenue }\end{array}$ & \\
\hline & $\begin{array}{l}1,000 \\
\text { boxes }\end{array}$ & $\$ / b o x$ & $\begin{array}{l}1,000 \\
\text { dollars }\end{array}$ & $\begin{array}{l}1,000 \\
\text { boxes }\end{array}$ & $\$ / b o x$ & $\begin{array}{l}1,000 \\
\text { dollars }\end{array}$ & $\begin{array}{l}1,000 \\
\text { dollars }\end{array}$ \\
\hline \multicolumn{8}{|l|}{ Baseline } \\
\hline Early Tangerines & 2,630 & 9.50 & 24,985 & 1,720 & 1.02 & 1,754 & 26,734 \\
\hline Honey Tangerines & 1,791 & 10.40 & 18,626 & 859 & 1.30 & 1,117 & 19,743 \\
\hline Navel Oranges & 3,591 & 6.45 & 23,162 & 1,809 & 0.33 & 597 & 23,759 \\
\hline \multicolumn{8}{|l|}{ With Citrus Canker } \\
\hline Early Tangerines & 1,566 & 29.55 & 46,273 & 2,349 & 1.02 & 2,396 & 48,669 \\
\hline Honey Tangerines & 954 & 33.56 & 32,015 & 1,431 & 1.30 & 1,860 & 33,876 \\
\hline Navel Oranges & 1,944 & 16.28 & 31,648 & 2,916 & 0.33 & 962 & 32,607 \\
\hline
\end{tabular}

Table 2. Estimated economic impact of endemic citrus canker on annual returns of fresh and processed temple oranges and tangelos, 1999-2000 season.

\begin{tabular}{|c|c|c|c|c|c|c|c|}
\hline \multirow[t]{2}{*}{ Variety } & \multicolumn{3}{|c|}{ Fresh Fruit } & \multicolumn{3}{|c|}{ Processed Fruit } & \multirow{2}{*}{$\begin{array}{l}\text { On-Tree } \\
\text { Revenue }^{*}\end{array}$} \\
\hline & $\begin{array}{c}\text { Fresh } \\
\text { Utilization }\end{array}$ & $\begin{array}{c}\text { Fresh } \\
\text { On-Tree } \\
\text { Price }\end{array}$ & $\begin{array}{c}\text { Fresh } \\
\text { On-Tree } \\
\text { Revenue }\end{array}$ & $\begin{array}{l}\text { Processed } \\
\text { Utilization }\end{array}$ & $\begin{array}{c}\text { Processed } \\
\text { On-Tree } \\
\text { Price }\end{array}$ & $\begin{array}{c}\text { Processed } \\
\text { On-Tree } \\
\text { Revenue }\end{array}$ & \\
\hline & $\begin{array}{l}1,000 \\
\text { boxes }\end{array}$ & $\$ / b o x$ & $\begin{array}{l}1,000 \\
\text { dollars }\end{array}$ & $\begin{array}{r}1,000 \\
\text { boxes }\end{array}$ & $\$ / b o x$ & $\begin{array}{c}1,000 \\
\text { dollars }\end{array}$ & $\begin{array}{r}1,000 \\
\text { dollars }\end{array}$ \\
\hline \multicolumn{8}{|l|}{ Baseline } \\
\hline Temples & 440 & 5.60 & 2,464 & 1,510 & 1.66 & 2,507 & 4,971 \\
\hline Tangelos & 736 & 5.55 & 4,085 & 1,464 & 1.00 & 1,464 & 5,549 \\
\hline \multicolumn{8}{|c|}{ With Citrus Canker } \\
\hline Temples & 440 & 5.60 & 2,464 & 1,315 & 1.75 & 2,301 & 4,765 \\
\hline Tangelos & 736 & 5.55 & 4,085 & 1,244 & 1.00 & 1,244 & 5,329 \\
\hline
\end{tabular}


Table 3. Estimated economic impact of endemic citrus canker on F.O.B. revenue for early tangerines, honey tangerines, and navel oranges, 1999-2000 season.

\begin{tabular}{|c|c|c|c|c|c|c|c|}
\hline \multirow[t]{3}{*}{ Variety } & \multicolumn{3}{|c|}{ Without Citrus Canker } & \multicolumn{3}{|c|}{ With Endemic Citrus Canker } & \multirow{2}{*}{$\begin{array}{r}\text { Net } \\
\text { Effect }\end{array}$} \\
\hline & $\begin{array}{c}\text { Average } \\
\text { F.O.B.* } \\
\text { Price }\end{array}$ & Marketings & $\begin{array}{c}\text { Total } \\
\text { F.O.B. } \\
\text { Revenue }\end{array}$ & $\begin{array}{c}\text { Average } \\
\text { F.O.B. } \\
\text { Price }\end{array}$ & Marketings & $\begin{array}{c}\text { Total } \\
\text { F.O.B. } \\
\text { Revenue }\end{array}$ & \\
\hline & $\$ /$ carton & $\begin{array}{c}1,000 \\
\text { cartons }\end{array}$ & $\begin{array}{l}1,000 \\
\text { dollars }\end{array}$ & $\$ /$ carton & $\begin{array}{r}1,000 \\
\text { cartons }\end{array}$ & $\begin{array}{c}1,000 \\
\text { dollars }\end{array}$ & $\begin{array}{c}1,000 \\
\text { dollars }\end{array}$ \\
\hline Early Tangerines & 11.99 & 5,260 & 63,067 & 22.65 & 3,156 & 71,476 & 8,409 \\
\hline Honey Tangerines & 12.77 & 3,580 & 45,717 & 24.12 & 2,148 & 51,812 & 6,096 \\
\hline Navels & 8.89 & 7,182 & 63,848 & 13.97 & 4,309 & 60,200 & $-3,648$ \\
\hline F.O.B. Revenue & & & 172,632 & & & 183,488 & 10,856 \\
\hline
\end{tabular}

Table 4. Estimated economic impact of endemic citrus canker on F.O.B. cost for early tangerines, 1999-2000 season.

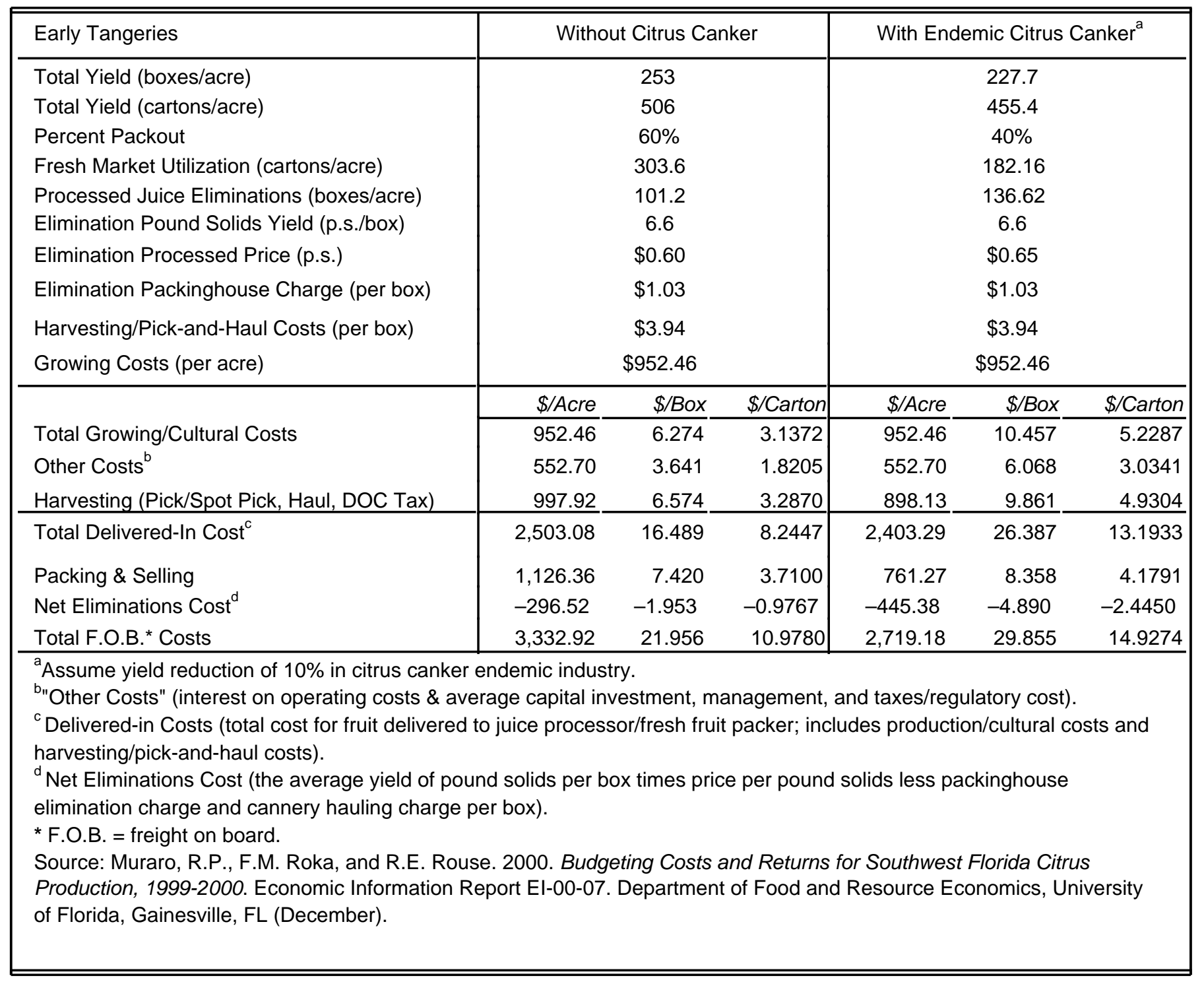


Table 5. Estimated economic impact of endemic citrus canker on F.O.B. cost for honey tangerines, 1999-2000 season.

\begin{tabular}{|c|c|c|c|c|c|c|}
\hline Honey Tangerines & \multicolumn{3}{|c|}{ Without Citrus Canker } & \multicolumn{3}{|c|}{ With Endemic Citrus Canker ${ }^{\mathrm{a}}$} \\
\hline Total Yield (boxes/acre) & \multicolumn{3}{|c|}{298} & \multicolumn{3}{|c|}{268.2} \\
\hline Total Yield (cartons/acre) & \multicolumn{3}{|c|}{596} & \multicolumn{3}{|c|}{536.4} \\
\hline Percent Packout & \multicolumn{3}{|c|}{$60 \%$} & \multicolumn{3}{|c|}{$40 \%$} \\
\hline Fresh Market Utilization (cartons/acre) & \multicolumn{3}{|c|}{357.6} & \multicolumn{3}{|c|}{214.56} \\
\hline Processed Juice Eliminations (boxes/acre) & \multicolumn{3}{|c|}{119.2} & \multicolumn{3}{|c|}{160.92} \\
\hline Eliminatin Pound Solids Yield (p.s./box) & \multicolumn{3}{|c|}{6.6} & \multicolumn{3}{|c|}{6.6} \\
\hline Elimination Processed Price (p.s.) & \multicolumn{3}{|c|}{$\$ 0.60$} & \multicolumn{3}{|c|}{$\$ 0.65$} \\
\hline Elimination Packinghouse Charge (per box) & \multicolumn{3}{|c|}{$\$ 1.03$} & \multicolumn{3}{|c|}{$\$ 1.03$} \\
\hline Harvesting/Pick-and-Haul Costs (per box) & \multicolumn{3}{|c|}{$\$ 3.35$} & \multicolumn{3}{|c|}{$\$ 3.35$} \\
\hline Growing Costs (per acre) & \multicolumn{3}{|c|}{$\$ 1,093.37$} & \multicolumn{3}{|c|}{$\$ 1,093.37$} \\
\hline & $\$ /$ Acre & $\$ / B o x$ & $\$ /$ Carton & $\$ /$ Acre & $\$ / B o x$ & $\$ /$ Carton \\
\hline Total Growing/Cultural Costs & $1,093.37$ & 6.115 & 3.0575 & $1,093.37$ & 10.192 & 5.0959 \\
\hline Other Costs ${ }^{b}$ & 552.70 & 3.091 & 1.5456 & 552.70 & 5.152 & 2.5760 \\
\hline Harvesting (Pick/Spot Pick, Haul, DOC Tax) & 997.92 & 5.581 & 2.7906 & 898.13 & 8.372 & 4.1859 \\
\hline Total Delivered-In Cost ${ }^{\mathrm{C}}$ & $2,643.99$ & 14.787 & 7.3937 & $2,544.20$ & 23.715 & 11.8577 \\
\hline Packing \& Selling & $1,326.70$ & 7.420 & 3.7100 & 881.48 & 8.217 & 4.1083 \\
\hline Net Eliminations Cost ${ }^{d}$ & -349.26 & -1.953 & -0.9767 & -524.60 & -4.890 & -2.4450 \\
\hline Total F.O.B. ${ }^{*}$ Costs & $3,621.43$ & 20.254 & 10.1270 & $2,901.08$ & 27.042 & 13.5210 \\
\hline $\begin{array}{l}{ }^{a} \text { Assume yield reduction of } 10 \% \text { in citrus can } \\
b^{b} \text { "Other Costs" (interest on operating/cultural } \\
\text { costs). } \\
{ }^{c} \text { Delivered-in Costs (total cost for fruit delive } \\
\text { and harvesting/pick-and-haul costs). } \\
{ }^{d} \text { Net Eliminations Cost (the average yield of } \\
\text { elimination charge and cannery hauling char } \\
\text { * F.O.B. = freight on board. } \\
\text { Source: Muraro, R.P., F.M. Roka, and R.E. F } \\
\text { Production, 1999-2000. Economic Informatio } \\
\text { University of Florida, Gainesville, FL (Decem }\end{array}$ & $\begin{array}{l}\text { demic indus } \\
\text { \& average } \\
\text { uice proces } \\
\text { solids per t } \\
\text { box). } \\
\text { 2000. Budg } \\
\text { ort El-00-07 }\end{array}$ & $\begin{array}{l}\text { apital inve } \\
\text { or/fresh fr } \\
\text { ox times } p \\
\text { eting Cost } \\
\text { Departme }\end{array}$ & $\begin{array}{l}\text { ment, mana } \\
\text { packer; in } \\
\text { e per poun } \\
\text { and Returns } \\
\text { of Food an }\end{array}$ & $\begin{array}{l}\text { ement, and } \\
\text { des produc } \\
\text { solids less } \\
\text { or Southwe } \\
\text { Resource }\end{array}$ & $\begin{array}{l}\text { taxes/regu } \\
\text { tion/cultura } \\
\text { ackinghou } \\
\text { t Florida C } \\
\text { conomics, }\end{array}$ & $\begin{array}{l}\text { tory } \\
\text { costs }\end{array}$ \\
\hline
\end{tabular}


Table 6. Estimated economic impact of endemic citrus canker on F.O.B. cost for navel oranges, 1999-2000 season.

\begin{tabular}{|c|c|c|c|c|c|c|}
\hline Navel Oranges & \multicolumn{3}{|c|}{ Without Citrus Canker } & \multicolumn{3}{|c|}{ With Endemic Citrus Canker ${ }^{a}$} \\
\hline Total Yield (boxes/acre) & \multicolumn{3}{|c|}{240} & \multicolumn{3}{|c|}{216} \\
\hline Total Yield (cartons/acre) & \multicolumn{3}{|c|}{480} & \multicolumn{3}{|c|}{432} \\
\hline Percent Packout & \multicolumn{3}{|c|}{$60 \%$} & \multicolumn{3}{|c|}{$40 \%$} \\
\hline Fresh Market Utilization (cartons/acre) & \multicolumn{3}{|c|}{288} & \multicolumn{3}{|c|}{172.8} \\
\hline Elimination Processed Juice (boxes/acre) & \multicolumn{3}{|c|}{96} & \multicolumn{3}{|c|}{129.6} \\
\hline Elimination Pound Solids Yield (p.s./box) & \multicolumn{3}{|c|}{5} & \multicolumn{3}{|c|}{5} \\
\hline Elimination Processed Price (p.s.) & \multicolumn{3}{|c|}{$\$ 0.60$} & \multicolumn{3}{|c|}{$\$ 0.65$} \\
\hline Elimination Packinghouse Charge (per box) & \multicolumn{3}{|c|}{$\$ 1.03$} & \multicolumn{3}{|c|}{$\$ 1.03$} \\
\hline Harvesting/Pick-and-Haul Costs (per box) & \multicolumn{3}{|c|}{$\$ 4.16$} & \multicolumn{3}{|c|}{$\$ 4.16$} \\
\hline Growing Costs (per acre) & \multicolumn{3}{|c|}{$\$ 837.15$} & \multicolumn{3}{|c|}{$\$ 837.15$} \\
\hline Additional Costs (per acre): Copper Application & \multicolumn{3}{|c|}{-} & \multicolumn{3}{|c|}{$\$ 32.36$} \\
\hline & $\$ /$ Acre & $\$ / B o x$ & $\$ /$ Carton & $\$ /$ Acre & $\$ / B o x$ & $\$ /$ Carton \\
\hline Total Growing/Cultural Costs & 837.15 & 5.814 & 2.9068 & 869.51 & 10.064 & 5.0319 \\
\hline Other Costs ${ }^{\mathrm{b}}$ & 552.70 & 3.838 & 1.9191 & 552.70 & 6.397 & 3.1985 \\
\hline Harvesting (Pick/Spot Pick, Haul, DOC Tax) & 997.92 & 6.930 & 3.4650 & 898.13 & 10.395 & 5.1975 \\
\hline Total Delivered-In Cost ${ }^{c}$ & $2,387.77$ & 16.582 & 8.2909 & $2,320.34$ & 26.856 & 13.4279 \\
\hline Packing \& Selling & $1,068.48$ & 7.420 & 3.7100 & 755.03 & 8.739 & 4.3694 \\
\hline Net Eliminations Cost ${ }^{d}$ & -189.12 & -1.313 & -0.6567 & -287.71 & -3.330 & -1.6650 \\
\hline Total F.O.B. ${ }^{*}$ Costs & $3,267.13$ & 22.688 & 11.3442 & $2,787.66$ & 32.265 & 16.1323 \\
\hline \multicolumn{7}{|c|}{ 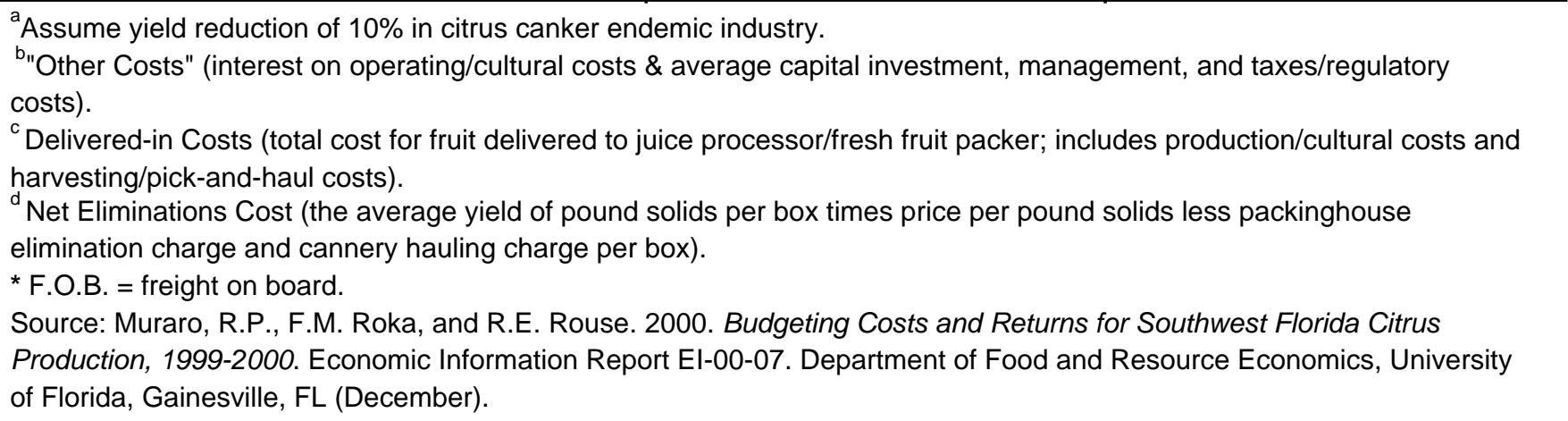 } \\
\hline
\end{tabular}


Florida's Citrus Canker Eradication Program (CCEP): Annual Economic Impact on Florida's....

Table 7. Estimated economic impact of endemic citrus canker on F.O.B. cost for tangelos, 1999-2000 season.

\begin{tabular}{|c|c|c|c|c|c|c|}
\hline Tangelos & \multicolumn{3}{|c|}{ Without Citrus Canker } & \multicolumn{3}{|c|}{ With Endemic Citrus Canker ${ }^{\mathrm{a}}$} \\
\hline Total Yield (boxes/acre) & \multicolumn{3}{|c|}{195} & \multicolumn{3}{|c|}{175.5} \\
\hline Total Yield (cartons/acre) & \multicolumn{3}{|c|}{390} & \multicolumn{3}{|c|}{351} \\
\hline Percent Packout & \multicolumn{3}{|c|}{$60 \%$} & \multicolumn{3}{|c|}{$40 \%$} \\
\hline Fresh Market Utilization (cartons/acre) & \multicolumn{3}{|c|}{234} & \multicolumn{3}{|c|}{140.4} \\
\hline Elimination Processed Juice (boxes/acre) & \multicolumn{3}{|c|}{78} & \multicolumn{3}{|c|}{105.3} \\
\hline Elimination Pound Solids Yield (p.s./box) & \multicolumn{3}{|c|}{6.6} & \multicolumn{3}{|c|}{6.6} \\
\hline Elimination Processed Price (p.s.) & \multicolumn{3}{|c|}{$\$ 0.60$} & \multicolumn{3}{|c|}{$\$ 0.65$} \\
\hline Elimination Packinghouse Charge (per box) & \multicolumn{3}{|c|}{$\$ 1.03$} & \multicolumn{3}{|c|}{$\$ 1.03$} \\
\hline Harvesting/Pick-and-Haul Costs (per box) & \multicolumn{3}{|c|}{$\$ 5.12$} & \multicolumn{3}{|c|}{$\$ 5.12$} \\
\hline Growing Costs (per acre) & \multicolumn{3}{|c|}{$\$ 837.15$} & \multicolumn{3}{|c|}{$\$ 837.15$} \\
\hline Additional Costs (per acre): Copper Application & \multicolumn{3}{|c|}{-} & \multicolumn{3}{|c|}{$\$ 32.36$} \\
\hline & $\$ /$ Acre & $\$ / B o x$ & $\$ /$ Carton & $\$ /$ Acre & $\$ / B o x$ & $\$ /$ Carton \\
\hline Total Growing/Cultural Costs & 837.15 & 7.155 & 3.5776 & 869.51 & 12.386 & 6.1931 \\
\hline Other Costs ${ }^{\mathrm{b}}$ & 552.70 & 4.724 & 2.3620 & 552.70 & 7.873 & 3.9366 \\
\hline Harvesting (Pick/Spot Pick, Haul, DOC Tax) & 997.92 & 8.529 & 4.2646 & 898.13 & 12.794 & 6.3969 \\
\hline Total Delivered-In Cost ${ }^{\mathrm{c}}$ & $2,387.77$ & 20.408 & 10.2041 & $2,320.34$ & 33.053 & $\overline{16.5266}$ \\
\hline Packing \& Selling & 868.14 & 7.420 & 3.7100 & 606.34 & 8.637 & 4.3187 \\
\hline Net Eliminations Cost ${ }^{d}$ & -228.54 & -1.953 & -0.9767 & -343.28 & -4.890 & -2.4450 \\
\hline Total F.O.B. * Costs & $3,027.37$ & 25.875 & 12.9375 & $2,583.40$ & 36.801 & 18.4003 \\
\hline \multicolumn{7}{|c|}{ 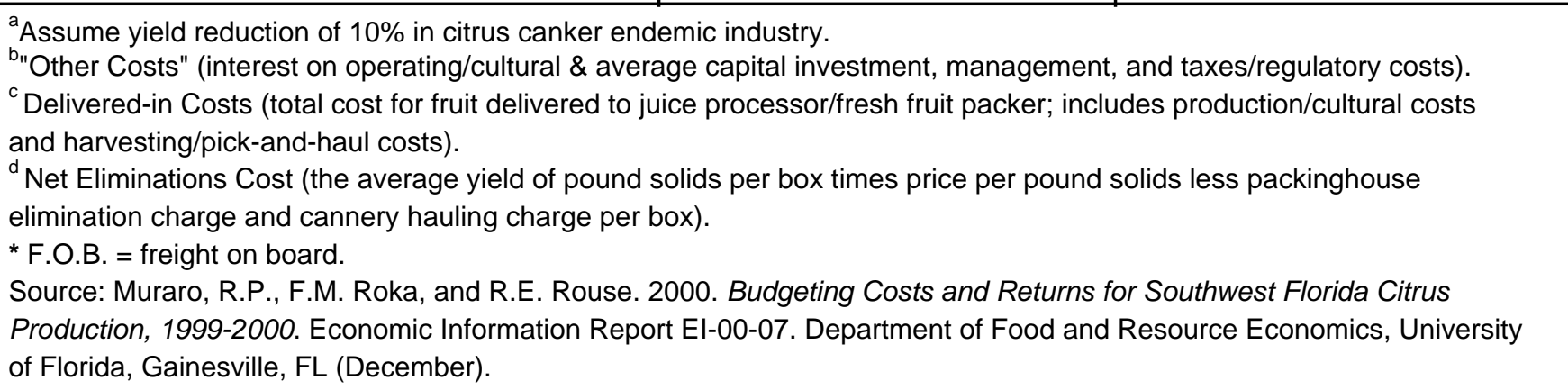 } \\
\hline
\end{tabular}


Table 8. Estimated economic impact of endemic citrus canker on F.O.B. cost for temple oranges, 1999-2000 season.

\begin{tabular}{|c|c|c|c|c|c|c|}
\hline Temple Oranges & \multicolumn{3}{|c|}{ Without Citrus Canker } & \multicolumn{3}{|c|}{ With Endemic Citrus Canker ${ }^{\mathrm{a}}$} \\
\hline Total Yield (boxes/acre) & \multicolumn{3}{|c|}{336} & \multicolumn{3}{|c|}{302.4} \\
\hline Total Yield (cartons/acre) & \multicolumn{3}{|c|}{672} & \multicolumn{3}{|c|}{604.8} \\
\hline Percent Packout & \multicolumn{3}{|c|}{$60 \%$} & \multicolumn{3}{|c|}{$40 \%$} \\
\hline Fresh Market Utilization (cartons/acre) & \multicolumn{3}{|c|}{403.2} & \multicolumn{3}{|c|}{241.9} \\
\hline Elimination Processed Juice (boxes/acre) & \multicolumn{3}{|c|}{134.4} & \multicolumn{3}{|c|}{181.44} \\
\hline Elimination Pound Solids Yield (p.s./box) & \multicolumn{3}{|c|}{6.6} & \multicolumn{3}{|c|}{6.6} \\
\hline Elimination Processed Price (p.s.) & \multicolumn{3}{|c|}{$\$ 0.60$} & \multicolumn{3}{|c|}{$\$ 0.65$} \\
\hline Elimination Packinghouse Charge (per box) & \multicolumn{3}{|c|}{$\$ 1.03$} & \multicolumn{3}{|c|}{$\$ 1.03$} \\
\hline Harvesting/Pick-and-Haul Costs (per box) & \multicolumn{3}{|c|}{$\$ 2.97$} & \multicolumn{3}{|c|}{$\$ 2.97$} \\
\hline Growing Costs (per acre) & \multicolumn{3}{|c|}{$\$ 837.15$} & \multicolumn{3}{|c|}{$\$ 837.15$} \\
\hline \multirow[t]{2}{*}{ Additional Costs (per acre): Copper Application } & \multicolumn{3}{|c|}{-} & \multicolumn{3}{|c|}{$\$ 32.36$} \\
\hline & $\$ /$ Acre & $\$ / B o x$ & $\$ /$ Carton & $\$ /$ Acre & $\$ / B o x$ & $\$ /$ Carton \\
\hline Total Growing/Cultural Costs & 837.15 & 4.153 & 2.0763 & 869.51 & 7.188 & 3.5942 \\
\hline Other Costs ${ }^{\mathrm{b}}$ & 552.70 & 2.742 & 1.3708 & 552.70 & 4.569 & 2.2846 \\
\hline Harvesting (Pick/Spot Pick, Haul, DOC Tax) & 997.92 & 4.950 & 2.4750 & 898.13 & 7.425 & 3.7125 \\
\hline Total Delivered-In Cost $^{c}$ & $2,387.77$ & $\overline{11.844}$ & 5.9220 & $2,320.34$ & 19.183 & 9.5913 \\
\hline Packing \& Selling & $1,495.87$ & 7.420 & 3.7100 & 982.98 & 8.127 & 4.0633 \\
\hline Net Eliminations Cost ${ }^{d}$ & -393.79 & -1.953 & -0.9767 & -591.49 & -4.890 & -2.4450 \\
\hline Total F.O.B. ${ }^{*}$ Costs & $3,489.85$ & 17.311 & 8.6554 & $2,711.83$ & 22.419 & 11.2096 \\
\hline \multicolumn{7}{|c|}{ 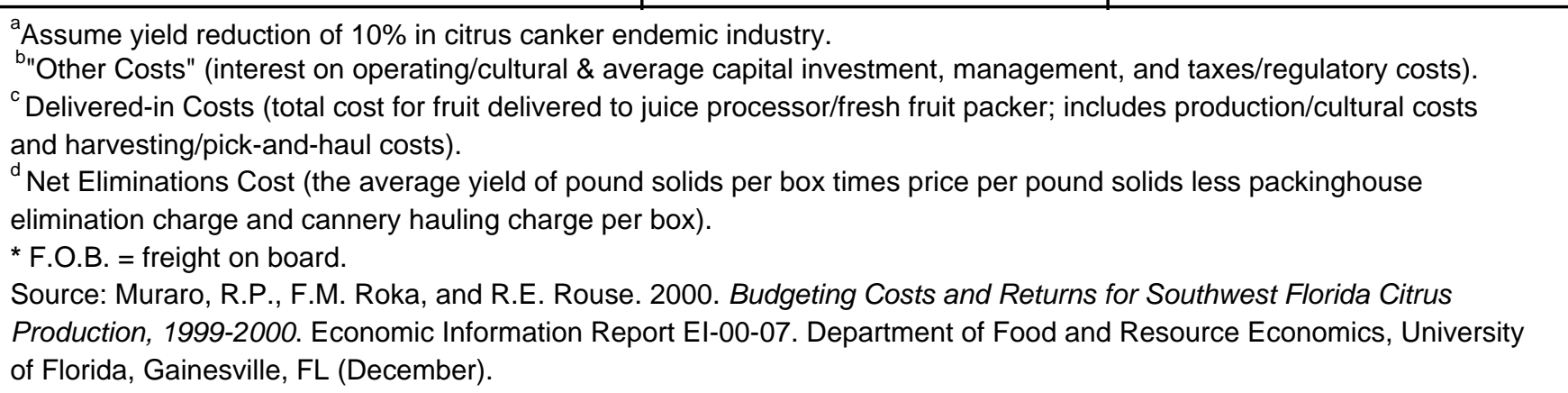 } \\
\hline
\end{tabular}


Table 9. Estimated changes in F.O.B. production costs associated with endemic citrus canker in the Florida citrus industry for early tangerines, honey tangerines, navel oranges, tangelos, and temple oranges.

\begin{tabular}{|c|c|c|c|c|c|}
\hline \multirow[b]{2}{*}{ Variety } & \multicolumn{4}{|c|}{ Packinghouse Fruit } & \multirow{2}{*}{$\begin{array}{l}\text { Net Change } \\
\text { in Costs }\end{array}$} \\
\hline & \multicolumn{2}{|c|}{ Production } & \multirow{2}{*}{$\frac{\text { F.O.B. }{ }^{*} \text { Cost }}{\$ / \text { carton }}$} & \multirow{2}{*}{$\frac{\text { Total F.O.B. Cost }}{1,000 \text { dollars }}$} & \\
\hline Without Citrus Canker & 1,000 boxes & 1,000 cartons & & & 1,000 dollars \\
\hline Early Tangerine & 2,650 & 5,300 & 10.98 & 58,194 & - \\
\hline Honey Tangerine & 4,350 & 8,700 & 10.13 & 88,131 & - \\
\hline Navel & 5,400 & 10,800 & 11.34 & 122,472 & - \\
\hline Temple & 733 & 1,466 & 8.66 & 12,696 & - \\
\hline Tangelo & 1,227 & 2,454 & 12.94 & 31,755 & $=$ \\
\hline \multicolumn{6}{|l|}{ With Citrus Canker } \\
\hline Early Tangerine & 2,385 & 4,770 & 14.93 & 71,216 & 13,022 \\
\hline Honey Tangerine & 3,915 & 7,830 & 13.52 & 105,862 & 17,731 \\
\hline Navel & 4,860 & 9,720 & 16.13 & 156,784 & 34,312 \\
\hline Temple & 733 & 1,466 & 11.21 & 16,434 & 3,738 \\
\hline Tangelo & 1,227 & 2,454 & 18.40 & 45,154 & 13,399 \\
\hline
\end{tabular}

Table 10. Estimated net change in revenues for fresh and processed specialty fruit associated with endemic citrus canker.

\begin{tabular}{|c|c|c|c|}
\hline \multirow[t]{2}{*}{ Variety } & \multicolumn{3}{|c|}{$\begin{array}{l}\text { On-tree Revenue* } \\
1,000 \text { dollars }\end{array}$} \\
\hline & Without Citrus Canker & With Citrus Canker & Net Change in Revenue \\
\hline \multicolumn{4}{|l|}{ Fresh Market } \\
\hline Early Tangerines & 24,985 & 46,273 & 21,288 \\
\hline Honey Tangerines & 18,626 & 32,015 & 13,389 \\
\hline Navel Oranges & 23,162 & 31,645 & 8,483 \\
\hline Temples & 2,464 & 2,464 & 0 \\
\hline \multirow[t]{2}{*}{ Tangelos } & 4,085 & 4,085 & 0 \\
\hline & & d Net Revenue Change: & 43,160 \\
\hline \multicolumn{4}{|l|}{ Processed Market } \\
\hline Early Tangerines & 1,754 & 2,396 & 642 \\
\hline Honey Tangerines & 1,117 & 1,860 & 743 \\
\hline Navel Oranges & 598 & 962 & 365 \\
\hline Temples & 2,507 & 2,301 & -206 \\
\hline \multirow[t]{2}{*}{ Tangelos } & 1,464 & 1,244 & -220 \\
\hline & & d Net Revenue Change: & 1,323 \\
\hline
\end{tabular}


Table 11. Estimated net change in F.O.B. revenues for specialty citrus fruit associated with endemic citrus canker.

\begin{tabular}{|lccc|}
\hline \hline \multirow{2}{*}{ Variety } & \multicolumn{3}{c|}{$\begin{array}{c}\text { F.O.B. }{ }^{*} \text { Revenue } \\
\text { 1,000 dollars }\end{array}$} \\
\cline { 2 - 4 } & Without Citrus Canker & With Citrus Canker & Net Change in Revenue \\
\hline Early Tangerine & 63,067 & 71,476 & 8,409 \\
Honey Tangerine & 45,717 & 51,812 & 6,096 \\
Navel Oranges & 63,848 & 60,200 & $-3,648$ \\
& \multicolumn{2}{c}{ Estimated Net F.O.B. Revenue Change: } \\
\hline F.O.B. = freight on board. & & 10,856 \\
\hline \hline
\end{tabular}

Table 12. Estimated net change in production cost of specialty fruit.

\begin{tabular}{|c|c|c|c|}
\hline \multirow[t]{2}{*}{ Variety } & \multicolumn{3}{|c|}{$\begin{array}{c}\text { Total Production Costs } \\
1,000 \text { dollars } \\
\end{array}$} \\
\hline & Without Citrus Canker & With Citrus Canker & Net Cost Change \\
\hline \multicolumn{4}{|l|}{ Packinghouse } \\
\hline Early Tangerines & 58,194 & 71,216 & 13,022 \\
\hline Honey Tangerines & 88,131 & 105,862 & 17,731 \\
\hline Navel Oranges & 122,472 & 156,784 & 34,312 \\
\hline Temples & 12,696 & 16,434 & 3,738 \\
\hline Tangelos & 31,755 & 45,154 & 13,399 \\
\hline & & Estimated Cost Change: & 82,201 \\
\hline
\end{tabular}

Table 13. Summary of annual net effect and economic impact of citrus canker on F.O.B. revenue and on delivered-in costs of Florida's specialty citrus fruit.

\begin{tabular}{|lcc|}
\hline \hline & & $\begin{array}{c}\text { Net Change } \\
1,000 \text { dollars }\end{array}$ \\
\hline Increase in Delivered-In Costs & & \\
Less Net Increase in Revenue & 44,483 \\
Increase in On-Tree Revenue* & 10,856 & \\
Increase in F.O.B. ${ }^{* *}$ Revenue & & 55,339 \\
Total Net Increase in Revenue & 26,862 \\
Total Annual Net Increase Costs & \\
\hline${ }^{*}$ On-Tree Revenue (farm gate price after harvesting/pick-and-haul cost have been subtracted). & \\
${ }^{* *}$ F.O.B. = freight on board. & \\
\hline \hline
\end{tabular}

